\title{
Committees: Human Rights Bodies
}

\section{A. Introduction}

1. "Human rights bodies" are international and regional non-judicial bodies which address human rights issues, normally under a particular treaty. For the purposes of this entry, human rights bodies only includes bodies which receive and deal with complaints about human rights abuses, or those which will have that capacity once the treaty that creates that process comes into force. All of these bodies may be termed "quasi-judicial bodies" as, while they are not courts, they have the function of determining relevant facts and (international) law in certain disputes.

2. For example, the United Nations (UN) treaty bodies operate to supervise and monitor the implementation of each of the nine core human rights treaties. These bodies are the Human Rights Committee (HRC), the $\rightarrow$ Committee on Economic Social and Cultural Rights (CESCR) [MPEPIL], the $\rightarrow$ Committee on the Elimination of Racial Discrimination (CERD), the $\rightarrow$ Committee on the Elimination of Discrimination against Women (CEDAW Committee), the $\rightarrow$ Committee against Torture (CAT Committee), the $\rightarrow$ Committee on the Rights of the Child (CRC Committee), the $\rightarrow$ Committee on the Protection of the Rights of All Migrant Workers and Members of their Families (CMW), the $\rightarrow$ Committee on the Rights of Persons with Disabilities (CRPD Committee), and the $\rightarrow$ Committee on Enforced Disappearances (CED Committee). There is one more treaty body, the $\rightarrow$ Sub-Committee on the Prevention of Torture (SPT), which operates under the Optional Protocol to the Convention against Torture. It is not discussed here as it does not have the capacity to receive and address complaints.

3. The $\rightarrow$ Working Group on Arbitrary Detention (WGAD) is a special procedure created in 1991 (United Nations Commission on Human Rights Resolution 1991/42) to investigate and make decisions regarding alleged violations of the right to be free from arbitrary detention. Its mandate derives from norms in the Universal Declaration on Human Rights (UDHR) and the International Covenant on Civil and Political Rights (ICCPR), especially Article 9 of both instruments. It may be distinguished from the other bodies discussed here as it is not established under any particular treaty. Instead, it is a 'Charter-based body' as it was established by the UN Commission on Human Rights and currently serves under the auspices of the UN Human Rights Council. The Commission and its successor, the Council, and their subsidiary bodies, derive their authority from the UN Charter rather than from a specific human rights treaty.

4. There are also regional human rights bodies. The Inter-American Commission on Human Rights (IACHR) operates under the auspices of the Organisation of American States (OAS). Its governing documents are the human rights instruments adopted by the OAS, including the American Convention on Human Rights 1969 (ACHR) and the American Declaration on the Rights and Duties of Man 1948 American Declaration).

5. The African Commission on Human Rights (AfCHR) operates within the regional human rights system developed under the auspices of the African Union, with its governing instruments 
being the human rights documents adopted within that system. Its main governing instruments are the African Charter on Human and People's Rights 1981 (ACHPR) and its Protocols.

6. The European Committee on Social Rights (ESCR) operates under the European Social Charter 1961, its Protocols and the Revised Charter of 1996 (ESC). These treaties protect a range of economic and social rights. All States within the Council of Europe may become a party. Member States may choose to accept to be bound by only some of the provisions therein, but they are encouraged to progressively agree to be bound by all of the provisions.

7. Human rights bodies have similar functions. Almost all of the human rights bodies are competent to determine individual complaints ("communications") on violations of the relevant treaty. The $\mathrm{CMW}$ will have that capacity once the relevant mechanism comes into force. Some of the UN treaty bodies, as well as the IACHR and the AfCHR, are also competent to receive and determine interstate communications. The ESCR does not receive individual complaints, but is empowered to receive and determine collective complaints. Most human rights bodies, excepting the IACHR and the ESCR, receive and address state reports on the implementation of the relevant treaty. All bar the ESCR have extra interpretative powers, such as in the issuance of General Comments which elucidate particular provisions of the relevant governing instrument. Some also have investigative capacities, whereby they can be proactive in investigating and reporting on a particular human rights issue, either within one or a number of States parties, under their governing treaty. Human rights bodies also engage in follow-up of their recommendations, so they can draw attention to the fact that a State has either complied or failed to comply with their rulings.

8. Human rights bodies are not international or regional courts, unlike, for example, the European Court of Human Rights or the Inter-American Court of Human Rights. Therefore, a State's failure to comply with the decisions of such bodies does not, of itself, constitute a breach of its international law obligations.

9. The HRC has stated that States parties have a duty to 'cooperate' with it (General Comment 33, para 15), arising from the general duty of States to behave in good faith towards their treaty obligations (Vienna Convention on the Law of Treaties, Art 26). This statement would logically apply to all of the UN treaty bodies, which share the HRC's quasi-judicial status. Cooperation seems to fall short of a requirement of complete compliance. However, the routine failure of a State to comply with the determinations of a human rights body, especially if such failure is accompanied by a lack of any serious attempt to engage with the relevant decision, is evidence of that State's bad faith towards the relevant binding international treaty obligations.

10. The International Court of Justice (ICJ) addressed the status of the decisions of such bodies in its decision in the Case concerning Ahmadou Sadio Diallo (Republic of Guinea v Democratic Republic of the Congo, p 639). In the case, the ICJ is influenced by the case law of the HRC and the AfCHR in interpreting, respectively, the ICCPR and the ACHPR. The ICJ states that it is not obliged to 'model its own interpretation of the [ICCPR] on that of' the HRC (Republic of Guinea v Democratic Republic of the Congo, 664). However, it went on, at 664, to say that it 'should ascribe great weight to the interpretations adopted' by the HRC, so as to 'achieve 
the necessary clarity and the essential consistency of international law, as well as legal security, to which both the individuals with guaranteed rights and the States obliged to comply with treaty obligations are entitled'. Similarly, in relation to the AfCHR, the ICJ stated, at 664, that it had 'to take due account of the interpretation' of regional instruments 'adopted by the independent bodies which have been specifically created ... to monitor the sound application of the treaty in question'.

11. Hence, it is likely that the ICJ will generally follow the interpretations of international human rights treaties that are delivered by treaty bodies attached to the relevant treaties. As the ICJ delivers internationally binding decisions in the exercise of its jurisdiction in contentious cases, its imprimatur can translate the authoritative decisions of human rights bodies into legally binding precedents from the ICJ.

12. While UN treaty body decisions are generally considered to be of themselves non-binding, an exception arguably lies with regard to their requests for interim measures. This matter is discussed below.

\section{B. Membership}

13. Human rights bodies have varying numbers of members. For example, the CAT Committee (Convention Against Torture and other Cruel, Inhuman and Degrading Treatment or Punishment (CAT), Art 17) has ten members while the CEDAW Committee (Convention on the Elimination of all Forms of Discrimination against Women (CEDAW), Art 17) has 23 members. There are seven members of the IACHR (ACHR, Art 34), 11 members of the AfCHR (ACHPR, Art 31), and 15 members of the ESCR (Committee of Ministers of the Council of Europe, Decision 4.2 (2001)).

14. Members of such bodies should have relevant human rights expertise (see, eg, ICCPR, Art 28(2)), though they do not have to have a legal background. They serve in their individual capacities rather than as representatives of their respective State governments (see, eg, ICCPR, Art 28(3)). Members are nominated by their State of nationality, and elected by States parties to the relevant treaties for a term of office. In the regional systems, States may nominate more than one person (three in the Americas (ACHR, Art 36(2)) and two in Africa (ACHPR, Art 34)).

15. All of the human rights bodies are required to have a diverse geographical membership, reflecting different cultures and legal systems. The more recently established UN treaty bodies, namely the CPRD and CED Committees, have requirements regarding balanced gender representation as well as, in the case of the CPRD Committee, appropriate representation of experts with disabilities.

16. Members of the UN treaty bodies serve four-year terms, with term limits applied under some of the UN treaties. For example, there is no term limit for HRC members, but CPRD Committee members may only serve two consecutive terms (Convention on the Rights of Persons with Disabilities (CPRD), Art 34(7)). In the case of the WGAD, one member from each of the five UN regions is appointed by the UN Human Rights Council for one six-year term. 
17. IACHR members serve up to two four-year terms (ACHR, Art 37). AfCHR members serve sixyear renewable terms. ESCR members serve six-year terms (Rules of the ESCR, Rule 6), which may be renewed once. The AfCHR also has the capacity to unanimously vote a Commissioner out, if its members believe that a member has ceased to discharge his or her duties 'for reasons other than a temporary absence' (ACHPR, Art 39(2)).

18. The human rights bodies are part-time bodies that meet periodically to carry out their work. For example, the HRC meets three times per year for three-week periods, while relevant Working Groups convene outside the plenary meeting. The WGAD meets at least three times a year for just over a week each time (Working Methods of WGAD, para 4).

19. The AfCHR meets at least twice a year for two weeks each time for its Ordinary Sessions (Rules of Procedure of the AfHCR, Rule 26). It may also convene Extraordinary Sessions at the request of the majority of Commission members or the Chairperson of the African Union Commission (Rules of Procedure of the AfHCR, Rule 27). Extraordinary Sessions allow the AfCHR to deal with emergency situations in a timely manner, but they also facilitate the AfCHR in getting through its ordinary workload. States may participate in its meetings, as can national human rights institutions and NGOs with observer status.

20. The ESCR meets seven times a year, roughly every two months, for four-day sessions. The IACHR meets for both ordinary and extraordinary meetings, for one-week sessions about six times a year.

21. The UN bodies meet in Geneva, where most of the UN human rights machinery is based. The ESCR meets in the home city of the Council of Europe, Strasbourg. In contrast, the IACHR and AfCHR meet in different places throughout their respective regions, rather than always meeting in their headquarter cities (see, eg, Rules of Procedure of the AfHCR, Rule 28(1)).

22. All human rights bodies elect Chairpersons and other officers who serve internal terms, and also Working Groups for select tasks. They also appoint individual members, known as "special rapporteurs", to serve in specific roles such as liaising with a particular State or dealing with communications.

23. The members of the IACHR are supplemented by other persons who serve in positions appointed by the IACHR (Rules of Procedure of the IACHR, Art 15). A number of rapporteurships are distributed amongst its seven members. A rapporteur has special responsibility for a particular human rights issue, which may relate to the human rights record of a particular State, or a particular issue. Some IACHR rapporteur positions are filled by persons who are not elected to the IACHR but who are elected by a majority of the IACHR pursuant to a competitive process. Such is the case for example, at the time of writing with the IACHR's Special Rapporteur on Economic, Social, Cultural and Environmental Rights.

24. The same process takes place in the AfCHR, which has created a number of subsidiary mechanisms (Rules of Procedure of the AfCHR, Chapter 5). Some of the roles in these mechanisms, entailing Committees (eg on the Prevention of Torture in Africa), Working Groups (eg on the Rights of Older Persons and People with Disabilities) and rapporteurships (eg on Freedom of Expression and Access to Information), are distributed amongst AfCHR 
members themselves. However, some of the appointments come from outside the AfCHR. These bodies present sessional reports to the AfCHR.

\section{Reporting Procedures}

25. "Reporting procedures" refer to procedures whereby States parties to relevant treaties periodically report on their implementation of that treaty to the relevant human rights body.

26. In the UN treaty body system, States must submit initial reports, which are due within a year or two of ratification of (or accession to) the relevant treaty (see eg ICCPR, Art 40(1)). Subsequent reports are then submitted, ideally in compliance with intervals dictated by the relevant human rights body. The interval for UN treaty bodies is normally around four to five years. It is significantly shorter for the CERD Committee, which requests periodic reports every two years (International Convention on the Elimination of All Forms of Racial Discrimination (ICERD), Art 9(b)).

27. A State's report is compiled by its own bureaucracy. In considering that report, the human rights body will normally have access to other sources of information, such as "shadow reports" from civil society organisations, national human rights institutions. The UN bodies are open to receiving information from other parts of the UN, including its specialised agencies such as UNESCO, while regional bodies will hear from specialised regional agencies.

28. The State's report is then examined by the relevant UN treaty body in a dialogue with government representatives from the relevant State. The dialogue will take about a day and a half for the initial report, and one day for subsequent periodic reports. A number of State reports are examined in each session of each human rights body. The dialogues are conducted in open session, and are now webcast.

29. Towards the end of a UN treaty body's meeting, the members adopt "Concluding Observations" on the reports of each of the States examined in the meeting by consensus (see, eg, Working Methods of the CESCR Committee, paras 30-31). These observations serve as a type of "report card" for the state on its implementation of the relevant treaty. They contain the relevant human rights body's conclusions on areas where the State has improved or excelled, factors and difficulties which hamper implementation of the treaty (which may or may not be within the State's control), and areas of concern. They will always contain recommendations for future action by the State to increase its treaty compliance. There is a follow-up procedure, whereby a special rapporteur from the UN treaty body will maintain dialogue with the State to monitor implementation of the recommendations in the Concluding Observations (see, eg, Working Methods of the HRC, Part IV).

30. The AfCHR also operates a reporting procedure, whereby States parties to the African Charter report on its implementation every two years (ACHPR, Art 62). The reporting procedure is similar to the UN procedure, whereby reports are prepared by States, discussed in dialogue with the AfCHR, and are then the subject of Concluding Observations and followup. The AfCHR also considers material from shadow reports prepared by civil society during this process. 
31. A reporting procedure also operates before the ESCR. Member States report periodically and regularly on their implementation of ESC provisions. The reporting schedule is quite complicated as it differs according to the right at issue, as well as on whether or not a State accepts collective complaints (see below). The reports are examined by the ESCR, which publishes its Conclusions on the report, including on the extent to which a Member State is complying with its ESC obligations. The Conclusions are not followed up by the ESCR but by the Committee of Ministers of the Council of Europe, which is comprised of all of the Foreign Ministers of the Members States of the Council of Europe. It is advised in this respect by the Governmental Committee of the European Social Charter and European Code of Social Security. Matters arising under ESCR Conclusions, including any follow-up, will ultimately return to the ESCR in its next reporting cycle, or by way of a collective complaint (see below).

32. The IACHR has no equivalent formal reporting procedure. States members of the OAS do prepare annual reports for other OAS organs, namely the Executive Committees of the InterAmerican Economic and Social Council and the Inter-American Council for Education, Science and Culture. States must transmit these reports to the IACHR (ACHR, Art 42), though there is no formal review of those reports by the IACHR.

33. There is no equivalent reporting procedure before the WGAD.

\section{Individual Communications: UN bodies}

\section{Procedure}

34. All UN treaty bodies (except for the SPT) have, or will have, the capacity to receive individual communications which concern allegations that a State has breached an individual's rights under a relevant treaty. The individual communications procedure for the CMW has not yet come into force: ten States are required to make the requisite declaration under Article 77 of the International Convention on the Protection of the Rights of All Migrant Workers and Members of Their Families (Migrant Workers Convention) before the procedure is activated. That number had not yet been reached at the time of writing.

35. Individual communications procedures are normally optional. A State can be a party to the relevant treaty yet not permit the filing of individual communications against it. In the UN, the individual communications procedure is often prescribed in a separate treaty to the main treaty, such as the first Optional Protocol to the ICCPR, or the Optional Protocol to the International Covenant on Economic, Social, and Cultural Rights (ICESCR): States must ratify that separate treaty in order to allow for the submission and consideration of individual communications against it. Sometimes the individual communications procedure is prescribed in a provision in the main treaty. For example, the individual communications procedure under the ICERD is prescribed in Article 14 of that treaty: States accept the procedure by making a declaration under that provision. Article 77 of the Migrant Workers Convention is another example of such a provision.

36. An exception in this regard within the UN is the WGAD. It can receive communications regarding instances of arbitrary detention against any State, without the need for that State to have explicitly permitted the submission and consideration of such communications. 
Furthermore, it can initiate investigations of possible individual instances of arbitrary detention if it receives adequately substantiated allegations thereof.

37. Individual communications are submitted in writing to the relevant UN human rights body. There is no cost for doing so. Costs may be incurred in attaining legal assistance in compiling the communication. There is no requirement to attain such legal assistance. However, professional assistance is more likely to generate a well-constructed communication which ultimately vindicates the complainant.

38. In the UN treaty system, communications must concern an alleged violation which has been suffered, or will imminently be suffered by, an individual or a group of individuals. "Abstract" communications, those communications which are effectively actio popularis, are not admissible: there must be a communication concerning at least one actual alleged victim (see, eg, Rules of Procedure of the HRC, Rule 96(b)). Victims do not have to submit the communication themselves. They can authorise another person to do so on their behalf (see, eg, Rules of Procedure of the HRC, Rule 96(b)). If a victim is unable to submit a communication, and is unable to authorise another person to do so, communications can still be submitted (see, eg, Rules of Procedure of the HRC, Rule 96(b)). Such a situation might arise if, for example, the alleged victim is dead or has disappeared. In such circumstances, the person who submits the communication must establish a close connection to the victim, such as a family connection.

39. Communications can be submitted on behalf of a group of individuals, so long as the alleged violation suffered by each member of the group is very similar. Communications cannot be submitted on behalf of artificial legal people, such as corporations (see, eg, Rules of Procedure of the HRC, Rule 96(a)).

40. Communications can be joined together if they involve identical or very similar fact situations (see, eg, Rules of Procedure of the HRC, Rule 94(2)), even if that means the complaint may lie against more than one State (see eg Soltes $v$ Czech Republic and Slovak Republic). Complaints by more than one person can also be severed (see, eg, Rules of Procedure of CAT Committee, Rule 111(5)).

41. If a communication satisfies basic criteria, such as details of the complainant's identity, it will generally be communicated to the relevant State with a request for its comments on both admissibility and merits within a certain time period. The complainant is then given an opportunity to comment on the State's arguments. This process may be repeated. Eventually, the human rights body will proceed to make a decision on admissibility, and, if necessary, merits, as explained below. A similar process takes place before WGAD though there is no formal admissibility phase. In certain rare cases of blatant inadmissibility, a UN treaty body may declare a communication to be inadmissible without transmitting it to the State concerned.

42. Sometimes States fail to respond to requests for their comments or arguments on the relevant communication. In such a case, the human rights body will nevertheless proceed to consider admissibility and, if necessary, merits. Certain presumptions might then be made in favour of the complainant, as the State has chosen not to rebut the arguments put against it 
in the communication. States should not receive any benefit of the doubt due to its noncooperation in the individual communications process.

43. Generally, the process of submitting evidence takes place in writing. Exceptionally in the UN system, there is provision for the receipt of oral evidence before some bodies. The HRC has allowed for oral evidence since late 2016, following in the footsteps of the CAT Committee and the CRC Committee (see, eg, Rules of Procedure under the Optional Protocol to the Convention on the Rights of the Child on a communications procedure, Rule 19). Such a proceeding may occur in situations where the case raises complex issues of fact or domestic law, or important questions of treaty interpretation (Human Rights Committee, Guidelines on making oral comments concerning communications). Oral procedures remain rare.

44. The process of deliberation by a UN treaty body over individual communications takes place in closed sessions (see, eg, Optional Protocol to CEDAW, Art 7(2)). The UN treaty body itself will not release any information publicly about a communication until it has ceased its consideration thereof.

45. Such cessation will arise if the communication is found to be inadmissible, or when a final decision on the merits is reached. In both instances, the final decision is made public. However, in some circumstances the UN body may choose not to identify the complainant: this often happens if a communication is found to be inadmissible. Cessation of consideration also arises if a communication is withdrawn, but the communication is not routinely made public in such instances.

46. The consideration of communications may be suspended at the request of a party, either the complainant or the State, after both sides have had an opportunity to comment on the request for suspension. Suspension may be appropriate in some circumstances in light of significant developments regarding the facts of the communication. A UN body may also choose to discontinue consideration, which terminates the communication.

\section{Interim orders}

47. UN bodies may request that a State implement 'interim measures' with regard to a communication (see, eg, Optional Protocol to CEDAW, Art 5). Such requests may be issued upon the request of the complainant, though they are only issued at the discretion of the relevant UN body. Interim measures arise when there is a perceived danger that irreparable harm will be suffered by the alleged victim in the period between submission of the communication and its final disposal. Examples of such irreparable harm are the execution of a person, and the deportation of a person who is challenging the human rights compliance of that deportation. Hence, relevant requests for interim measures would involve a request that the State refrain from such execution or deportation during the consideration of the communication. A request for interim measures does not imply that the communication gives rise to actual violations by the State, nor that it is even admissible.

48. If a request for interim measures is made, States can ask for the request to be lifted. Such State requests are transmitted to the complainant for their comments. It is then up to a special rapporteur or a working group to decide whether to accede to the State's request. 
49. Non-compliance with interim measures manifests extreme disrespect and even contempt for the relevant individual communications process. Instances thereof are heavily condemned by the relevant human rights body. For example, in Piandiong $v$ Philippines (para 5.2), the HRC claimed that a State 'commits grave violations of its obligations under the Optional Protocol if it acts to prevent or frustrate consideration by the Committee of a communication ... or to render examination by the Committee moot and the expression of its Views nugatory and futile'. The HRC has also stated that a failure to comply with interim measures is 'incompatible with the obligation to respect in good faith the procedure of individual communications established under the Optional Protocol' (General Comment 33, para 19).

50. Those comments by the HRC give rise to the question of whether its requests for interim measures, and those of other UN treaty bodies, are legally binding (Naldi, 449). If so, that would lend requests for interim measures a status that is not shared by a relevant body's ultimate final decision on the merits. Such a legal duty would be grounded in the general obligation of States to act with good faith towards the treaties that they are party to (Vienna Convention on the Law of Treaties, Art 26). While 'good faith' may only require 'cooperation' with the UN treaty bodies with regard to most of their decisions (General Comment 33, para $15)$, it arguably requires full compliance with interim measures.

51. The equivalent procedure for WGAD is called the 'urgent action' procedure (Methods of Work of the WGAD, Part V). WGAD will send an urgent request to a State to take measures with regard to a detained person when it has good reason to believe that that person's health or life is endangered by continued detention. Such appeals serve a humanitarian purpose: they do not pre-judge any individual communication that WGAD might be considering.

\section{Admissibility}

52. Strict admissibility criteria are prescribed for and applied by all of the UN bodies, apart from the WGAD. If a communication is found to be inadmissible, the process of consideration ends and the final inadmissibility decision is published. If a communication is found to be admissible, the body may proceed immediately to consider the merits and then release the final decision on admissibility and merits at the same time. A UN treaty body may however choose to split up considerations of admissibility and merits. If this occurs, further rounds of argument from the State and the complainant are sought and submitted after an admissibility decision and prior to final merits consideration. A separation of admissibility and merits is more likely with regard to more complex communications.

53. Decisions regarding admissibility do not have to be made by consensus; they can be made by a majority. Dissenting members may submit separate opinions on admissibility. Members may also agree with the majority finding on admissibility, but nevertheless choose to submit separate reasons. Such separate opinions are not as common for admissibility decisions as they are for merits decisions, which are discussed below. 
54. The various requirements for admissibility are now discussed. Their complexity is not necessarily reflected in the discussion below, which outlines the basic rules rather than outlying complications.

55. Submissions must not be anonymous (see, eg, Optional Protocol to CPRD, Art 2(a)). While anonymity for complainants might be maintained by a UN body, the body itself and its secretariat support must be able to identify the alleged victim and the person who is submitting the communication.

56. The communication must be admissible ratione temporis (see, eg, Optional Protocol to CPRD, Art 2(f)). This means that the alleged events giving rise to the alleged violation occur after the date at which the individual communications procedure came into force for the relevant State. For example, suppose State $X$ ratifies the Optional Protocol to the ICCPR, and that treaty comes into force for that State on 1 January, 2018. The relevant events referred to in any subsequent Optional Protocol communication against State $\mathrm{X}$ must arise after 1 January, 2018. Individual communications procedures are not retrospective in their application to States.

57. There is an exception to the ratione temporis rule. "Continuing violations", that is those which commence prior to the relevant date but which continue after that date, are not inadmissible under the ratione temporis rule. This doctrine of continuing violations is complex, and is applied with varying degrees of strictness by the various UN treaty bodies.

58. There must not be an abuse of the right of petition (see, eg, Optional Protocol to CPRD, Art 2 (b)). This ground of inadmissibility may relate to a number of instances, though it is rarely invoked. One example might be the very late submission of an individual communication, as discussed below. Other examples might be utterly frivolous or vexatious communications, or ones containing abusive language.

59. The individual communication must contain sufficient substantiation of a relevant human rights violation (see, eg, Optional Protocol to CPRD, Art 2(e)). For example, simple assertions without any accompanying evidence are unlikely to be admissible. However, human rights bodies do not impose requirements of strict formal language upon complainants, especially as many complainants lack human rights law expertise.

60. The matters referred to in an individual communication must concern matters within the jurisdiction of a State that has accepted the individual communications procedure (see, eg, Optional Protocol to ICESCR, Art 2). Hence, the facts as alleged must be capable of giving rise to a relevant violation that the State party is feasibly responsible for. Most obviously, such responsibility will arise where the alleged violation has arisen due to the act or omission of an agent of the respondent State. Examples of state agents include governments, police officers, prison officers in public prisons, and public servants.

61. It is now well accepted that a State can also be responsible for an act or omission of a nonState actor if the State has failed to exercise due diligence in preventing, investigating, or punishing a non-State actor for the relevant act or omission. 
62. The matter must also relate to alleged facts which arise within the territorial jurisdiction of the State. In some circumstances, a State will be responsible for events which arise outside its own territory. This will occur if a State exercises effective control over territories beyond its own, such as in the case of the occupation of external territory. Generally, a State is also responsible for the acts perpetrated upon a person outside its territory if its agents have effective control over that person, or effective control over that person for the purposes of the right at issue. For example, a State is responsible for the actions of its embassies and consulates in refusing passports to citizens, which impact on that person's freedom of movement. The international law regarding the extraterritorial responsibilities of States is complex and evolving.

63. The communication cannot be simultaneously under consideration under another procedure of international investigation of settlement (see, eg, Optional Protocol to the ICCPR, Art $5(2)(a))$. That is, the communication cannot be the subject of an individual petition to another human rights body, or a regional human rights court. The "same communication" for such purposes must relate to the same victim/s, and substantially the same facts. Under some communications systems, this rule applies not only to simultaneous consideration, but also to any previous international consideration of the communication (see, eg, Optional Protocol to the CRC on a communications procedure, Art 7(4)). That is, there is a rule that the communication must never have been the subject of another communications procedure.

64. The most common reason for inadmissibility is that domestic remedies must be exhausted prior to the submission of the communication to the relevant body (See eg Optional Protocol to ICESCR, Art 3(1)). Victims of human rights abuses are meant to pursue local remedies so long as they are available and effective, and are not overly prolonged (see eg Optional Protocol to ICESCR, Art 3(1)). There are many instances where human rights bodies will deem this admissibility hurdle to be complied with, even though local remedies have not been pursued. It may be that there is no relevant available remedy in a particular State with regard to a particular abuse, in which case this admissibility criterion is essentially satisfied at the time of submission. It may be that available remedies are not effective as, for example, the person might face persecution or reprisals due to any attempt to pursue such remedies. Complainants are not required to pursue remedies which are objectively futile, nor are they required to pursue remedies which are not capable of yielding a satisfactory resolution to their communication.

65. There are differing rules within human rights bodies regarding time limits for submission of communications. Some human rights bodies require that communications be submitted within a certain time period after the exhaustion of the final local remedy in a State. For example, the CESCR Committee requires that communications be submitted to it within one year of the exhaustion of the final remedy in a State, unless such submission was for some reason impossible (Optional Protocol to ICESCR, Art 2(a)). No such rule strictly applies to submissions of communications under the Optional Protocol to the ICCPR to the HRC. However, very late submissions can be dismissed by the HRC on the basis that they are an abuse of process: the HRC now adopts a presumption that submissions which arise five years after the exhaustion of a final remedy are inadmissible as abuses of process, unless there are compelling reasons for the delay (Rules of Procedure of the HRC, Rule 96(c)). 
66. There is no formal consideration of admissibility by the WGAD.

\section{Merits}

67. If a communication is deemed to satisfy all admissibility criteria, the human rights body will then address the merits of the communication. Sometimes the merits will be considered immediately upon adoption of a decision that the communication is admissible. In other instances, the two stages of admissibility and communication are split, and the respective parties are given another chance to address arguments to the relevant human rights body (see eg Rules of Procedure of the HRC, Rules 99-100).

68. Merits decisions are released to both the State and the complainant, and are eventually made public. Such decisions may entail findings of non-violation, a finding or findings of violation, or a mixture of both. The latter finding may arise where there are allegations of multiple violations in a communication, which is common.

69. If there are no findings of violation, that is the end of the matter.

70. If there are findings of violation, the UN body will make recommendations to the State on how to remedy such violations. Recommended remedies can take many forms. For example, they might entail changes to legislation and practice, and the payment of compensation to victims. The matter will then be followed up by a rapporteur from the relevant treaty body, who will report on the compliance or non-compliance by the State in question (see eg Rules of Procedure of CAT Committee, Rule 120). The follow-up rapporteur's conclusions are made public, which can put some pressure on non-complying States to comply.

71. A UN body's 'merits decision' reflects the consensus decision of the majority of the body. Individual members may submit individual separate opinions (see eg Rules of Procedure of CAT Committee, Rule 120), which might concur with the majority decision, or dissent from it, or dissent in part. As noted, separate opinions may also relate to admissibility. A separate opinion may represent the opinion of an individual member, or may be co-signed by multiple members, thus representing the opinion of more than one member.

72. The WGAD, after the process of receiving arguments from the complainant and the State and after its own deliberations, ultimately makes one of five decisions (Methods of Work of the WGAD, Part C). First, if the person has been released, it files the communication but it may nevertheless choose to give an opinion on whether that person was arbitrarily detained. Secondly, it may decide that the relevant case does not involve an instance of arbitrary detention. Thirdly, it may keep the case open pending further information. Fourthly, it may file the case if it lacks sufficient information, either temporarily or permanently. Fifthly, it may decide that there is a case of arbitrary detention and hence make appropriate recommendations to the State concerned. It publishes its decisions annually.

73. The WGAD will consider requests to review its decision on the basis of new evidence (Methods of Work of WGAD, Part D). 


\section{E. Individual Communications before the IACHR and the AfCHR}

74. The IACHR also operates an individual communications system. It may make decisions pursuant to the rights under each of the OAS human rights instruments. States parties to the ACHR automatically allow for individual petitions (ACHR, Art 44). For those States that are not a party, individual communications may be submitted under the American Declaration (Rules of Procedure of the IACHR, Art 51). Therefore, the individual communications system is not optional within the OAS.

75. Most proceedings are conducted in writing, though the IACHR may choose to hold a hearing with the consent of the parties (Rules of Procedure of the IACHR, Art 68). It is also possible for the IACHR to conduct on-site investigations in relation to a communication (Rules of Procedure of the IACHR, Art 39).

76. The admissibility criteria before the IACHR are similar to those before the UN bodies. However, the IACHR does not dismiss communications as actio popularis, so it has a more flexible approach than the UN bodies in that regard.

77. The IACHR can also adopt 'precautionary measures', which are its equivalent to the UN bodies' interim measures (Rules of Procedure of the IACHR, Art 25). These can also arise independently of an individual communication, as explained below.

78. A key difference to the UN procedures is the IACHR's conciliation role. It will seek to reach a friendly settlement between the parties if possible (Rules of Procedure of the IACHR, Art 40). If such a settlement is reached, the IACHR publishes a short statement of the facts and the solution reached.

79. If the communication is admissible and a friendly settlement is not reached, the IACHR will make a merits decision. If no violation is found, the parties are notified and the decision is published. If a violation is found, a preliminary report is sent to the relevant State. The IACHR will make recommendations towards provision of a remedy, such as cessation of acts of violation, the payment of compensation and/or changes to legislation.

80. The IACHR may decide by majority vote to publish its final report three months later. Separate opinions may be appended. It will then follow up the report with the parties to monitor compliance. This is also the case with friendly settlements.

81. If a State fails to comply with the recommendations in the preliminary report, the IACHR by majority may decide to refer the matter to the Inter-American Court of Human Rights, so long as the State is a party to the ACHR (Rules of Procedure of the IACHR, Art 45). In doing so, it must take into account the wishes of the petitioner and the nature and importance of the communication. States can also refer communications to the Court. In such instances, the Court will take submissions from the complainant, the IACHR, and the State. The IACHR must appear in all cases before the Court (ACHR, Art 57).

82. The AfCHR operates, in this regard, similarly to the IACHR. The individual communications system is compulsory (ACHPR, Art 55): States cannot opt out. It operates similar admissibility 
criteria to the IACHR, including an analogous lenient approach to the issue of actio popularis. Its interim measures requests are known as requests for 'provisional measures' (Rules of Procedure of the AfCHR, Rule 98). It may also offer its offices to facilitate an amicable resolution of the matter if the communication is found to be admissible (ACHPR, Art 52). It may also hear oral evidence, as well as receive evidence from third parties such as other States, including amicus curiae briefs (Rules of Procedure of the AfCHR, Rule 99-100). Dissenting or otherwise separate opinions in AfCHR decisions are not recorded or published.

83. As with the IACHR, the AfCHR may refer cases to a regional court, in its case the African Court on Human and People's Rights (African Court), if it believes that a State has failed, or is unwilling, to comply with its recommendations with respect to a communication (Rules of Procedure of the AfCHR, Rule 118). It may also refer a communication to court "'at any stage of [its] examination ... if it deems necessary' (Rules of Procedure of the AfCHR, Rule 118(4)). It may also escalate requests for interim measures to the African Court if it believes that a State has not complied with the request.

84. The Court may also transfer cases to the AfCHR under Article 6(3) of the Protocol to the ACHPR on the Establishment of the African Court of Human and People's Rights (African Court Protocol) for a determination of admissibility, or it may request the AfCHR's opinion on admissibility (African Court Protocol Art 6(1)). In matters before the African Court, the AfCHR may be represented by one or more Commissioners (Rules of Procedure of the AfCHR, Rule 120).

85. If a series of communications indicates that there is a situation of 'serious or massive violations of human rights' in a State, the AfCHR will bring that matter to the attention of the Assembly of Heads of State and Government of the African Union, as well as the Peace and Security Council of the African Union (Rules of Procedure of the AfCHR, Rule 79). It may then be duly requested under Article 58 of the ACHPR to 'undertake an in-depth study' of the situation, and write up a report. The AfCHR may also choose to refer such matters to the African Court (African Court Protocol, Art 5).

\section{F. Collective Complaints before the ESCR}

86. The ESCR receives and makes decisions with regard to collective complaints rather than individual complaints. The system of collective complaints was introduced under the Additional Protocol to the European Social Charter Providing for a System of Complaints of 1995 (Additional Protocol). The system is optional: Member States to the ESC do not have to ratify this Protocol.

87. Such complaints are submitted by certain non-governmental organisations (NGOs) and social partners (Additional Protocol, Art 1). An international NGO must have participatory status with the Council of Europe in order to be eligible to submit a complaint. The international social partners are the European Trade Union Confederation, representing employees, and two organisations representing employers, Business Europe and the International Organisation of Employers. National trade unions and employer groups may also submit complaints, subject to certain criteria. Member States may also authorise national NGOs to submit complaints, but only Finland had done so at the time of writing. 
88. The complaints must relate to the alleged non-compliance with ESC obligations of a State's law or practice. The State in question must be one which has accepted the collective complaints procedure, and the rights at issue must be ones which the State has accepted as legally binding upon it.

89. Admissibility requirements largely concern formalities, such as clear identification of the submitting organisation, and proof that the person submitting is entitled to represent that organisation. The complaint must be submitted in writing (Rules of the ESRC, Chapter II). A social partner must be sufficiently 'representative' of either workers or employers in order to be eligible to submit a collective complaint. A submitting NGO must have relevant expertise in the social rights at issue in a complaint in order to submit it. The complaint must identify the way in which a State's law or policy violates its ESC obligations. There is no requirement to exhaust local remedies, nor any requirement to identify any victim of a violation. Furthermore, a like complaint can be submitted to another international body without rendering an ESCR complaint inadmissible.

90. The process of considering a complaint is similar to that of the other human rights bodies, considered above. The State and the submitting organisation are given opportunities to submit arguments on the matter before the ESCR makes its admissibility decision, which is made public.

91. After the admissibility decision, the ESCR may request that a State adopt 'immediate measures' to mitigate the risk of serious damage arising prior to its merits decision (Rules of the ESRC, Chapter IV).

92. With regard to merits, the respondent State and the submitting organisation are given opportunities to submit arguments (Rules of the ESRC, Chapter III). This may arise during the admissibility stage to speed up the process. Other parties may also make submissions at the merits stage, including other States that have accepted the collective complaints procedure, as well as international employers' organisations and trade unions. Other organisations may also be invited to submit arguments at the discretion of the ESCR. All of the arguments are made public (Rules of the ESRC, Rule 37). Oral submissions may be made if the ESCR decides, again at its discretion, to hold a hearing (Rules of the ESRC, Rule 33).

93. Ultimately, the ESCR makes a merits Decision on whether the ESC has been violated. Any dissenting opinions are appended to the Decision. The Decision is communicated to the parties and to the Committee of Ministers. It is made public four months later, or at an earlier date (Rules of the ESRC, Art 35(4)).

94. As with the ESCR reporting process, the follow-up process is undertaken by the Committee of Ministers. The Committee of Ministers may not change the decision, but it is charged with the task of ensuring compliance. The relevant State must report on the matter in all of its subsequent reports until it complies with the Decision (Additional Protocol, Art 10).

\section{G. Interstate communications}


95. There is also scope for the submission of interstate communications, that is communications by State parties against other State parties, to some of the UN treaty bodies, namely the HRC, CAT Committee, CERD, and the CMW. In the UN, such communications may only be made by States that have made such a declaration: a State cannot be a petitioner without also allowing itself to be a respondent to such communications (see, eg, ICCPR, Art 41). As with individual communications, this process is normally optional, such that States parties have to expressly allow for such communications in order for them to take place. However, the interstate communication applies as a matter of right, exceptionally, under Art 11 of the ICERD.

96. The procedures regarding interstate communications vary amongst human rights bodies. They are not well developed within the UN system, as they have not been utilised until very recently. The first interstate communications in the UN human rights treaty system were submitted to the CERD Committee in early 2018. They consist of a communication by Palestine against Israel, and a communication by Qatar against, jointly, Saudi Arabia and the United Arab Emirates.

97. There are also interstate communication systems before the regional bodies. These have been used before both the IACHR and the AfCHR, but the number of communications is very low. States can choose to authorise the IACHR to receive interstate communications against it (ACHR, Article 45). Thus, the interstate communication system is optional unlike the individual communications system before the IACHR. In contrast, the relevant procedure before the AfCHR is a compulsory procedure for States parties to the ACHPR (Art 47).

98. There is no interstate communications procedure before the WGAD or the ESCR.

\section{H. General Comments}

99. The UN human rights bodies have the capacity to issue authoritative interpretations of, or guidance with regard to implementation of, provisions of the relevant treaty. All of the UN bodies have developed the practice of issuing "General Comments" which address various aspects of their respective treaties in detail (see eg ICCPR, Art 40(4)). These documents may also be known as General Recommendations, depending on which body they emanate from. General Comments normally constitute expanded interpretations of specific provisions of the relevant treaty. They may however address any matter under the treaty, such as reservations, reporting procedures, as well as issues which cut across numerous provisions of a treaty such as, in the case of CEDAW, issues relating to violence against women (CEDAW General Recommendation 19).

100. General Comments are adopted by consensus by the human rights bodies after consideration of drafts prepared by rapporteurs and working groups. There are now opportunities for States, other UN bodies, national human rights institutions, academics and civil society to submit comments on drafts prior to the body's final adoption of a General Comment. General Comments are not binding, but carry significant authoritative legal value.

101. The human rights bodies increasingly issue other documents, outside of their General Comments, to address matters of general interest. For example, the HRC issued 
Guidelines on measures of reparation in late 2016. The CESCR Committee has long issued Statements, as well as Open Letters from its Chair to States parties, on various topics, such as the relationship between ICESCR obligations and austerity measures.

102. The equivalent documents for WGAD are called "deliberations". These address matters of general interest related to arbitrary detention. Examples of the topics of deliberations include house arrest, the detention of migrants, and the scope of the right under customary international law.

103. Furthermore, WGAD will address certain thematic issues in a less formal detailed way in its annual reports. These are referred to on its website as 'issues in focus'. Examples of such issues are its brief discussion of 'detention in the context of drug control' in its 2015 annual report, and its discussion of 'military justice' in 2014.

104. The AfCHR also issues General Comments, as well as Guidelines. These are soft law documents which normally outline its view on a particular right, such as its General Comment 4 on the right to be free from torture, or its Guidelines on Combating Sexual Violence and its Consequences in Africa. It may also issue Advisory Opinions and recommendations to States parties to the African Union on human rights matters.

105. The IACHR does not issue documents like General Comments. Rather, it issues more in-depth studies on human rights issues, as explained below.

106. The ESCR does not issue interpretative documents beyond its work on State reports and collective complaints.

\section{Investigative Procedures}

107. Most UN bodies are empowered to carry out their own investigations into particular human rights abuses ( $\rightarrow$ Inquiry procedures: Human rights bodies). Such procedures are available to all UN bodies apart from the HRC and the CMW (see eg CAT, Art 20). The CERD's version of such procedures is an "urgent action/early warning" procedure, discussed below.

108. Investigations are more proactive than the reactive processes of responding to State reports and communications. Having said that, such investigations are prompted by the receipt of credible information relating to serious, grave or systemic violations by a State party to the relevant treaty.

109. The Inquiries procedure is optional: States may opt out of the inquiry procedure upon ratification of the relevant treaty (see eg CAT, Art 28). The Convention on Enforced Disappearances (CED) is an exception, as there is no opt-out option (CED, Article 33). Nevertheless, States parties are still required to consent in order for an on-site visit to take place (CED, Article 33(4)).

110. All inquiries are undertaken confidentially, and the cooperation of the relevant State party is sought at all stages. Inquiries may entail on-site visits by a designated member of the relevant UN treaty body, who may gather written and oral evidence. A detailed report is 
compiled by the human rights body and conveyed to the State party, which is then able to submit its views on the report. That report remains confidential. Follow-up activities may arise with regard to any inquiry. A summary of the report and its findings may be included in a UN treaty body's annual report after consultation with the relevant State.

111. The WGAD also has a procedure whereby it conducts country visits. These visits mirror like procedures for the other "special procedures" operating under the auspices of the UN Human Rights Council. WGAD visits take place at the invitation of the relevant State, so they do not arise from the initiative of the WGAD itself. Country visits may include followup visits. The WGAD compiles and submits reports of such visits to the Human Rights Council. These reports are made public.

112. The IACHR has a large investigative role (Rules of the IACHR, Art 39; ACHR, Art 41(c)). It reports on States at its own initiative (Rules of the IACHR, Art 60), as well as particular thematic areas (Rules of the IACHR, Arts 59(2)(d), 59(3) and 59(9)). There are a large number of thematic reports, with five to seven reports released each year. Topics include matters such as Indigenous women, poverty and human rights, and freedom of expression on the internet. It may also conduct on-site investigations with a view to reporting on specific human rights situations in particular States. Hearings may be held in respect of matters relating to the production of these reports. Hearings are generally public. States are given opportunities to make observations on reports prior to their publication, and those observations may prompt the IACHR to change their initial draft reports.

113. The AfCHR also has a significant investigative role. It conducts on-site and factfinding missions to investigate the situation of human rights on the ground in a State, especially if the State has been the subject of a large number of communications (see eg Rules of the AfCHR, Part 3, Chapter 2, and Rule 70). It may undertake a fact-finding mission at its own initiative, without the trigger of a particular communication. It may also investigate perceived crisis situations and matters relating to particular human rights themes. States members of the African Union are required to cooperate with such missions, including by undertaking not to engage in reprisals against anyone who provides information to the mission, and to facilitate the mission's access to documents and other evidence. It must also provide protection for the mission, and guarantee its freedom of movement (See Rules of the AfCHR, Rule 82).

\section{J. Early Warnings, Urgent Actions and Precautionary Measures.}

114. The CERD committee has a distinctive investigations procedure within the UN. Under CERD, an early warning procedure is designed to prevent an existing situation from escalating into conflict. An urgent action procedure is invoked to cease or limit the severity of violations arising from a situation (Report of the CERD Committee).

115. Both procedures may involve calling for a special report, and will often involve requesting specific measures to be taken on an urgent basis by a State. Both measures, which operate in a very similar manner, can be controversial as they involve the singling out of a particular State at the initiative of a human rights body. Unlike other investigative procedures, these CERD procedures do not entail on-site visits. 
116. The equivalent measure for the IACHR are its adoption of 'precautionary measures; (Rules of the IACHR, Art 25), which may be requested from a relevant State in urgent situations to prevent irreparable harm. The measures may concern one person, or a group of people. In certain situations, the IACHR may submit a request to the Inter-American Court of Human Rights to make a binding order for precautionary measures (Rules of the IACHR, Art 76). It may do so when, for example, a State fails to comply with its own request for precautionary measures, or when it otherwise believes a Court order is necessary for reasons of efficacy. The Court does not have to accede to the IACHR's request.

117. A similar system operates before the AfCHR: its emergency measures are called ;Urgent Appeals' (Rules of AfCHR, Rule 82(2)).

\section{K. Reform of the UN bodies}

118. There has been much agitation for significant reform of the UN treaty body system. The system is plagued by backlogs and a lack of cooperation by States.

119. A general problem with the UN treaty bodies' system is a lack of appropriate resources. Resourcing has not increased with workloads, which have gone up due to a variety of reasons such as increasing numbers of ratifications and communications.

120. In 2006, the then UN High Commissioner for Human Rights, Louise Arbour, proposed creating a unified standing treaty body to replace the part time treaty bodies (Concept Paper on the High Commissioner's Proposal for a Unified Standing Treaty Body). That proposal received very little political support. Indeed, such an initiative has probably been overtaken by proposals, largely from outside the UN, for a standing World Court of Human Rights, which would be a judicial body rather than a human rights body. The latter proposal has not however had much political support either.

121. Most of the reform proposals regarding the UN human rights treaty system have concerned the reporting process. The reporting process in the UN has long been afflicted by late reporting by States. In some instances, States have been late by over a decade. The UN treaty bodies have dealt with this issue by examining the records of States in the absence of a report, after calling for reports and the giving of notice (see eg Rules of Procedure of the HRC, Rule 70). Indeed, States can even be examined, again after due notice, in the absence of a State delegation (See eg Rules of Procedure of the HRC, Rule 68(2)). In the absence of a report, UN treaty bodies still have access to alternative sources of information, such as civil society organisations concerned with the relevant State.

122. However, State malfeasance is not the only problem in the reporting process. Reporting can be very onerous, particularly for developing States which may lack the resources to access and compile the information needed, especially for multiple UN treaty bodies. The task can also be quite burdensome in federal states, for example, where jurisdiction is shared between different levels of government. 
123. Furthermore, the UN treaty bodies lack the capacity and time to deal with all state reports in a timely fashion. Indeed, the system is arguably, to an extent, reliant on some lateness on the part of States in their reporting, as there would otherwise be extreme delays in addressing reports if all States reported on time. As it stands, there have sometimes been long delays between the submission of a report and its consideration by the relevant human rights body. Hence, there has long been an imperative to reform the reporting procedure in the UN.

124. States now submit a common core document, which covers matters of relevance to all of the UN treaty bodies (Harmonized guidelines on reporting under the international human rights treaties, including guidelines on a common core document and treaty-specific documents). Such a document might, for example, address the system of government in the State (eg unitarian, federal), the way in which it generally protects and enforces human rights (eg entrenched bill of rights, statutory charter, and so on), and the basic demography of the State. Such a document reduces the need to report on such matters over and over again.

125. Furthermore, country rapporteurs and working groups now compile lists of issues for States to help them, and other interested parties such as civil society organisations, focus their preparation for the report's examination (Treaty Bodies Lists of Issues Prior to Reporting).

126. The time allocated for the reviews of reports has been reduced, which enables the review of more reports in a single session. Of course, this reduction in time comes at the expense of the level of scrutiny of reports.

127. As noted, one reform has been to deal with long-term non-reporting by examining the State, despite the absence of a report. Another means to deal with this phenomenon has been to permit States to consolidate overdue reports upon submission (See eg Working Methods of CEDAW Committee, Part IV).

128. One possible reform is for the UN treaty bodies to adopt a coordinated predictable reporting schedule, which guarantees a State has reported to all relevant bodies within a particular period. Such a measure would not decrease or increase reporting obligations, but would bring some order to the system of periodicity. Such a system would assist States, treaty bodies and other stakeholders (eg civil society and national human rights institutions) to plan and manage their reporting workloads (Academy of International Humanitarian Law and Human Rights, 17-24).

129. Another way of managing backlogs is to consider State reports in separate chambers of the treaty body (Academy of International Humanitarian Law and Human Rights, 12). Both the CRC Committee and the HRC have at times temporarily adopted this method to clear backlogs.

130. The communications procedures within the UN have received less attention with regard to reform. However, backlogs are growing within that system, due to the increased number of communications procedures, ratifications, and complaints. Perhaps communications could be referred to a sub-group within a treaty body which concentrates 
only on communications. Perhaps a single body across all of the UN core treaties could deal with communications, though such a reform would require the unprecedented reopening of the treaties' texts to amendments. UN treaty bodies could be more proactive in swiftly dealing with communications which relate to the same structural deficiency within a State. Finally, certain communications could be prioritised where they are likely to set important new precedents, or concern especially serious abuses.

131. Greater alignment of the practices of the UN treaty bodies would be welcome (Academy of International Humanitarian Law and Human Rights, 27). The formulation of working methods and internal rules has largely taken place in a haphazard manner over time, which has contributed to some inconsistencies in practices. More formal and informal interactions should take place, with the Office of the High Commissioner for Human Rights playing a coordinating role. However, it may be noted that proposals for greater synergies have often been met by resistance from within the respective human rights bodies.

132. A final systemic problem with the UN human rights treaty system is a lack of $\rightarrow$ compliance [MPEPIL]. States often fail to implement the recommendations of UN treaty bodies arising from Concluding Observations, relevant communications, and in General Comments. The UN treaty bodies are hampered in this respect by the non-binding nature of their decisions. Compliance is ultimately a matter of sufficient political commitment from the State concerned, and the willingness of the international community at large to hold a recalcitrant State to account. However, UN treaty bodies can play a role in maximising State compliance by prioritising their credibility, and ensuring that their work is of the highest quality, so as not to give States an excuse for non-compliance by issuing inadequately reasoned decisions.

133. In 2014, the UN General Assembly passed Resolution 68/268 which acknowledged the importance of the UN human rights treaty system. It set in place a process whereby the topic and possible measures of treaty body reform would be reconsidered by that body in six years, that is in April 2020.

134. The same discussion regarding reform has not enveloped the WGAD, which has a lower profile than the UN treaty bodies. Its mandate is renewed every three years by the UN Human Rights Council, which has not taken the opportunity to significantly remodel the institution.

\section{Reform of regional human rights bodies}

135. The IACHR underwent a process of consultation regarding reform of its practices from 2011 to 2013, resulting in significant reform to its Rules. The reform process was prompted by a number of factors, including dissatisfaction with the IACHR's performance from a number of OAS States. The new Rules provide for greater transparency and predictability in its practices, such as in the IACHR's issuance of precautionary measures and consideration of individual communications. The changes have improved the IACHR's processes and credibility, and seem to have averted a crisis which potentially endangered the IACHR's future. 
136. The African human rights system underwent major reform with the creation of the African Court of Human Rights in 2006. Ongoing efforts at reform rarely focus on the AfCHR alone, and tend to be aimed at the whole African human rights system. Concerns relate, in the main, to compliance by States. Since 2015, the European Union has granted 10 million Euro to strengthen the African human rights system, with some money allocated to the work of the AfCHR in order to support its special procedures, the efficiency of its complaint mechanisms, and to reduce existing backlogs.

137. Regarding the ESRC, there is no formal dialogue or process of reform taking place, currently, within the Council of Europe. Of all the human rights bodies discussed here, the ESRC is the most efficient in terms of moving through its workload, but that is in part due to a continuing lack of knowledge of the collective complaints system. Ideas for reform from outside the ESRC tend to focus on a need to raise its profile, which pales in comparison to that of the European Court of Human Rights.

\section{Conclusion}

138. Human rights bodies may lack the powers and profile of judicial bodies, such as the European Court of Human Rights. Further, as noted directly above, ongoing constructive reform of these bodies is desirable. Their processes are, however, more diverse and flexible than those of judicial bodies, including reporting, investigative and general interpretative processes alongside their communications handling functions. Therefore, human rights bodies play a crucial role in generating and clarifying the detailed content of international human rights law, in conjunction with their role in overseeing the performance of States parties in implementing key human rights treaties and other instruments at the global and regional levels. 


\section{CITED BIBLIOGRAPHY}

Academy of International Humanitarian Law and Human Rights, "Optimizing the UN Treaty Body System: Academic Platform Report on the 2020 Review", May 2018

Naldi G, 'Interim Measures in the UN Human Rights Committee' (2004) 53 International and Comparative Law Quarterly 445

\section{FURTHER BIBLIOGRAPHY}

Alfredsson $\mathrm{G}$ and others (eds), International Human Rights Monitoring Mechanisms: Essays in Honour of Jakob Th. Möller (2nd rev. ed., Brill Nijhoff 2009)

Aportes DPLF (Magazine of the Due Process of Law Foundation), 'The Reform of the Inter-American Commission on Human Rights', Number 19, year 7, April 2014

B. G. Ramcharan, The Protection Roles of UN Human Rights Special Procedures (Martinus Nijhoff Publishers 2009)

Beyani C, 'Recent Developments in the African Human Rights System 2004-2006' (2007) 7 Human Rights Law Review 582

Buck T and Wabwile M, 'The Potential and Promise of Communications Procedures under the Third Protocol to the Convention on the Rights of the Child' (2013) 2 International Human Rights Law Review 205

Buckley C, Donald A and Leach P, Towards Convergence in International Human Rights Law: Approaches of Regional and International Systems (Brill Nijhoff 2016)

Cerna C, 'Duplication and Divergence in the Work of the United Nations Human Rights Treaty Bodies' (2011) 105 Proceedings of the Annual Meeting-American Society of International Law 507

Cullen H, 'The Collective Complaints System of the European Social Charter: Interpretative Methods of the European Committee of Social Rights' (2009) 9 Human Rights Law Review 61

Egan S, The United Nations Human Rights Treaty System: Law and Procedure (Bloomsbury Professional 2011)

--, 'Strengthening the United Nations Human Rights Treaty Body System' (2013) 13 Human Rights Law Review 209

Hampson FJ, 'Overview of the Reform of the UN Human Rights Machinery' (2007) 7 Human Rights Law Review 7

Johansen, $\mathrm{N}$ and Mikkola, N (eds), Reform of the European Social Charter: Seminar Presentations of 9 and 9 February 2011 (Ministry of Foreign Affairs of Finland, 2011)

Joseph, S and Castan, M, The International Covenant on Civil and Political Rights: Cases, Materials and Commentary (OUP, 2013, $3^{\text {rd }}$ ed)

Keller $\mathrm{H}$ and Marti C, "Interim Relief Compared: Use of Interim Measures by the UN Human Rights Committee and the European Court of Human Rights", (2013). Interim relief compared: use of 
interim measures by the UN Human Rights Committee and the European Court of Human Rights. 73. 325-372

Keller H and Ulfstein G, UN Human Rights Treaty Bodies: Law and Legitimacy (Cambridge University Press 2012)

Kozma, J, Nowak M and Scheinin M, A World Court of Human Rights: Consolidated State and Commentary (Neuer Wissenschaftlicher Verlag, Vienna, 2010)

Lukas K, 'The Collective Complaint Procedure of the European Social Charter: Some Lessons for the EU?' (2014) 41 Legal Issues of Economic Integration 275

M. Cherif Bassiouni and Schabas W, New Challenges for the UN Human Rights Machinery: What Future for the UN Treaty Body System and the Human Rights Council Procedures? (Intersentia 2011)

Malcolm D Evans, Murray R and Cambridge University Press, The African Charter on Human and Peoples' Rights: The System in Practice, 1986-2006 (2nd ed., Cambridge University Press 2008)

Morijn J, 'Reforming United Nations Human Rights Treaty Monitoring Reform' (2011) 58 Netherlands International Law Review 295

Murray R and Mottershaw E, 'Mechanisms for the Implementation of Decisions of the African Commission on Human and Peoples' Rights' (2014) 36 Human Rights Quarterly 349

Nowak M, 'Comments on the UN High Commissioner's Proposals Aimed at Strengthening the UN Human Rights Treaty Body System' (2013) 31 Netherlands Quarterly of Human Rights 3

O'Flaherty M, Human Rights and the UN: Practice before the Treaty Bodies (2nd ed., MNijhoff Publishers 2002)

--, 'The Concluding Observations of United Nations Human Rights Treaty Bodies' (2006) 6 Human Rights Law Review 27

- - 'The Dublin Statement on the Process of Strengthening of the United Nations Human Rights Treaty Body System' (2010) 28 Netherlands Quarterly of Human Rights 116

O'Flaherty M, 'Reform of the UN Human Rights Treaty Body System: Locating the Dublin Statement' (2010) 10 Human Rights Law Review 319

Pasqualucci JM, The Practice and Procedure of the Inter-American Court of Human Rights (2nd ed., Cambridge University Press 2013)

Pedone J and Kloster AR, 'New Proposals for Human Rights Treaty Body Reform' (2012) 22 Journal of Transnational Law \& Policy 29

Rodley N, 'Duplication and Divergence in the Work of the United Nations Human Rights Treaty Bodies: A Perspective from a Treaty Body Member' (2011) 105 American Society of International Law Proceedings 512

Saul, B, Mowbray J and Kinley D, The International Covenant on Economic, Social and Cultural Rights: Commentary, Cases and Materials (OUP, 2014) 
Schmidt MG, 'Follow-up to Decisions, Recommendations and Reports under United Nations Human Rights Procedures' (2014) 61 Nordic Journal of International Law 225

Sunga RAI, 'The Committee on Enforced Disappearances and Its Monitoring Procedures' (2012) 17 Deakin Law Review 151

'The Belfast Statement: The Response of National Human Rights Institutions to the United Nations High Commissioner for Human Rights Report on the Strengthening of the Human Rights Treaty Body System' (2013) 31 Netherlands Quarterly of Human Rights 116

Tyagi, Yogesh, The UN Human Rights Committee: Practice and Procedure (Cambridge University Press 2011)

Weissbrodt DS and Mitchell B, 'The United Nations Working Group on Arbitrary Detention: Procedures and Summary of Jurisprudence' (2016) 38 Human Rights Quarterly 655

\section{CITED DOCUMENTS}

African Charter on Human and Peoples' Rights (adopted 27 June 1981, entered into force 21 October 1986) 1520 UNTS 217

African Commission on Human and Peoples' Rights, General Comment no 4 on the African Charter on Human and Peoples' Rights: the Right to Redress for Victims of Torture and other Cruel, Inhuman and Degrading Treatment (Art. 5), adopted at the $21^{\text {st }}$ Extraordinary session (23 February to 4 March 2017), http://www.achpr.org/files/instruments/general-comment-right-toredress/achpr general comment no. 4 english.pdf

African Commission on Human and Peoples' Rights, Guidelines on Combating Sexual Violence and its Consequences in Africa, adopted at 60 $0^{\text {th }}$ Ordinary session (8-22 May 2017), http://www.achpr.org/files/instruments/combating-sexualviolence/achpr eng guidelines on combating sexual violence and its consequences.pdf

American Convention on Human Rights (signed 22 November 1969, entered into force 18 July 1978) 1144 UNTS 123

CEDAW, General Comment 19, "Violence against Women", 1992, UN doc A/47/38, pp 1-6.

Concept Paper on the High Commissioner's Proposal for a Unified Standing Treaty Body, UN doc $\mathrm{HRI} / \mathrm{MC} / 2006 / 2,22$ March 2006

Convention against Torture and other Cruel, Inhuman and Degrading Treatment or Punishment (adopted 10 December 1984, entered into force 26 June 1987) 1465 UNTS 85

Convention on the Elimination of All Forms of Discrimination against Women (adopted 18 December 1979, entered into force 3 September 1981) 1249 UNTS 13

Convention on the Rights of Persons with Disabilities (adopted 13 December 2006, entered into force 3 May 2008) 2515 UNTS 3

Convention on the Rights of the Child (adopted 20 November 1989, entered into force 2 September 1990) 1577 UNTS 3

Council of Europe, European Social Charter: Collected Texts (7 $7^{\text {th }}$ edition), 1 January 2015 
Committee on the Elimination of All Forms of Racial Discrimination, Guidelines for early warning and urgent action procedures, UN doc. A/62/18, Annexes Chapter III

European Social Charter (revised), published 3 May 1996, entered into force 1 July 1999, ETS 163

"Harmonized Guidelines on Reporting under the International Human Rights Treaties, Including Guidelines on a Common Core Document and Treaty-Specific Documents," HRI/MC/2006/3, 11 July 2006

Human Rights Committee, General Comment 33, UN doc CCPR/C/GC/33, 5 November 2008

Human Rights Committee, Guidelines on making oral comments concerning communications, https://www.ohchr.org/Documents/HRBodies/CCPR/GuidelinesOralHearings.pdf

Human Rights Committee, Guidelines on measures of reparation under the Optional Protocol to the International Covenant on Civil and Political Rights, UN doc. CCPR/C/158, 30 November 2016.

Inter-American Commission on Human Rights, Resolution 1/2013, Reform of the Rules of Procedure, Policies and Practices

International Convention for the Protection of All Persons from Enforced Disappearances (adopted 20 December 2006, entered into force 23 December 2010), 2716 UNTS 3

International Convention on the Elimination of all Forms of Racial Discrimination (adopted 21 December 1965, entered into force 4 January 1969) 660 UNTS 195

International Convention on the Protection of the Rights of All Migrant Workers and Members of Their Families (adopted 18 December 1990, entered into force 1 July 2003) 2220 UNTS 3

International Covenant on Civil and Political Rights (adopted 19 December 1966, entered into force 23 March 1976) 993 UNTS 171

International Covenant on Economic, Social and Cultural Rights (adopted 16 December 1966, entered into force 3 January 1976) 993 UNTS 3

Open Letter dated 16 May 2012 by the Chairperson of the Committee on Economic, Social and Cultural Rights to States parties to the International Covenant on Economic, Social and Cultural Rights on Austerity Measures,

https://tbinternet.ohchr.org/ layouts/treatybodyexternal/Download.aspx?symbolno=INT\%2fCESCR \%2fSUS\%2f6395\&Lang=en

Optional Protocol to the Convention on the Elimination of All Forms of Discrimination Against Women (adopted 6 October 1999, entered into force 20 December 2000) 2131 UNTS 83

Optional Protocol to the International Covenant on Civil and Political Rights (adopted 16 December 1966, entered into force 23 March 1976) 999 UNTS 302

Optional Protocol to the International Covenant on Economic, Social and Cultural Rights (adopted 10 December 2008, entered into force 5 May 2013, UN doc A/RES/63/117

Optional Protocol to the Convention on the Rights of the Child on a communications procedure (adopted 19 December 2011, entered into force 14 April 2014) UN doc A/RES/66/138 
Optional Protocol to the Convention on the Rights of Persons with Disabilities, adopted 13 December 2006, entered into force 3 May 2008, 2518 UNTS 283

Report of the CERD Committee, 70th and 71st sessions, 2007, UN doc. A/62/18, paras 17-30

Rules of Procedure of the African Commission on Human and Peoples' Rights, adopted May 12 to 26, 2010

Rules of Procedure of the CAT Committee, UN doc CAT/C/3/Rev. 6, 13 August 2013

Rules of Procedure of the CRC Committee under the Optional Protocol to the Convention on the Rights of the Child on a communications procedure, UN doc. CRC/C/62/3, 16 April 2013

Rules of Procedure of the Human Rights Committee, UN doc CCPR/C/3/Rev. 10, 11 January 2012

Rules of Procedure of the Inter-American Commission on Human Rights, as modified in the Session held from 8 to 22 March, 2013

"Treaty Bodies Lists of Issues Prior to Reporting", UN doc HRI/ICM/2010/3, 19 May 2010

United Nations Commission on Human Rights, "Question of Arbitrary Detention", UN doc E/CN.4/RES/1991/42, 5 March 1991.

Vienna Convention on the Law of Treaties, adopted 23 May 1969, comes into force 27 January 1980, 1155 UNTS 331.

Working Methods of the CEDAW Committee, https://www.ohchr.org/EN/HRBodies/CEDAW/Pages/WorkingMethods.aspx (accessed 14 September 2018)

Working Methods of the CESCR Committee, https://www.ohchr.org/EN/HRBodies/CESCR/Pages/WorkingMethods.aspx (accessed 14 September 2018)

Working Methods of the HRC, https://www.ohchr.org/EN/HRBodies/CCPR/Pages/WorkingMethods.aspx (accessed 14 September 2018)

Working Methods of the WGAD, UN doc A/HRC/36/38, 13 July 2017.

\section{FURTHER DOCUMENTS}

European Social Charter [https://www.coe.int/en/web/european-social-charter/europeancommittee-of-social-rights]

Governmental Committee of the European Social Charter and the European Code of Security [https://www.coe.int/en/web/european-social-charter/governmental-committee]

International Service for Human Rights, 'Simple Guide to the UN Treaty Bodies' $<$ www.ishr.ch/guides-to-the-un-system/simple-guide-to-treaty-bodies $>$

Office of the High Commissioner for Human Rights, 'The United Nations Human Rights Treaty System' (2012) Fact sheet 30 $<$ https://www.ohchr.org/Documents/Publications/FactSheet30Rev1.pdf> 
- -, 'Individual Complaint Procedures under the United Nations Human Rights Treaties' (2013) Fact sheet 7 <https://www.ohchr.org/Documents/Publications/FactSheet7Rev.2.pdf>

- - ' 'Human Rights Treaty Bodies - Individual Communications'

$<$ https://www.ohchr.org/EN/HRBodies/TBPetitions/Pages/IndividualCommunications.aspx\#theadmi ssibility> accessed 10 July 2018

- - 'Treaty Body Strengthening'

<https://www.ohchr.org/EN/HRBodies/HRTD/Pages/TBStrengthening.aspx> accessed 10 July 2018

Rules of Procedure of the CED Committee, UN doc. CED/C/1, 22 June 2012

Rules of Procedure of the CEDAW Committee, UN doc HRI/GEN/3/Rev.3, paras 93-126, 28 May 2008

Rules of Procedure of the CERD Committee, UN doc. CERD/C/35/Rev. 3, 1 January 1986

Rules of Procedure of the CERD Committee, UN doc. CERD/SP/2/Rev. 1, 10 November 1987

Rules of Procedure of the CESCR Committee, UN doc E/C.12/1990/4/Rev. 1, 1 September 1993

Rules of Procedure of the CESCR Committee under the Optional Protocol to the ICESCR, UN doc.

E/C.12/49/3

Rules of Procedure of the CPRD Committee, UN doc. CPRD/C/1/Rev. 1, 10 October 2016

Rules of Procedure of the CRC Committee, UN doc. CRC/C/4/Rev. 4, 18 March 2015

The Collective Complaints Procedure, https://www.coe.int/en/web/european-socialcharter/collective-complaints-procedure

'The Dublin Statement on the Process of Strengthening of the United Nations Human Rights Treaty Body System' <http://www2.ohchr.org/english/bodies/HRTD/docs/DublinStatement.pdf $>$ accessed 10 July 2018

Working Methods of the CAT Committee, https://www.ohchr.org/EN/HRBodies/CAT/Pages/WorkingMethods.aspx (accessed 14 September 2018)

Working Methods of the CED Committee, https://www.ohchr.org/EN/HRBodies/CED/Pages/WorkingMethods.aspx (accessed 14 September 2018)

Working Methods of the CERD Committee, https://www.ohchr.org/EN/HRBodies/CERD/Pages/WorkingMethods.aspx (acccessed 14 September 2018)

Working Methods on the CRC Committee, https://www.ohchr.org/EN/HRBodies/CRC/Pages/WorkingMethods.aspx (accessed 14 September 2018)

Working Methods of the CRPD Committee, UN doc. CRPD/C/5/4, 2 September 2011

\section{CITED CASES}


Case concerning Ahmadou Sadio Diallo, Republic of Guinea $v$ Democratic Republic of the Congo Judgment of 30 November 2010, ICJ Reports 2010

Piandiong v Philippines, UN doc CCPR/C/70/D/869/1999, 19 October 2000

Soltes v Czech Republic and Slovak Republic UN doc CCPR/C/85/D/1034-1035/2001, 28 October 2005

PIL Keywords : International Procedural Law / International Courts and Tribunals; Human rights ; United Nations Human Rights Committee [UNHRC] ; Committee on the Elimination of Discrimination against Women [CEDAW] ; Committee on the Rights of the Child [CRC] ;

Suggested Keywords : United Nations treaty bodies ; Individual complaint procedure ; Compliance ; Reporting procedure ; Quasi-judicial body. 